\title{
Managing Knowledge in Creating Archive Access in an Indonesian Records Center
}

\author{
$1^{\text {st }}$ Rizkiana Karmelia Shaura \\ Library and Information Science \\ Masters Program \\ Universitas Indonesia \\ Depok, Indonesia \\ karmeliashaura@gmail.com
}

\author{
$2^{\text {nd }}$ Ike Iswary Lawanda* \\ Library and Information Science \\ Department \\ Universitas Indonesia \\ Depok, Indonesia \\ iswary@ui.ac.id
}

\begin{abstract}
This paper investigates the construction of knowledge and knowledge management in the creation of record access in the records center of the Directorate General of Elementary and Secondary Education in the Ministry of Education and Culture Republic of Indonesia. Record officers in this organization have no archival competence, and we aim to establish ways to innovate and manage activities within the processing units to create a records security classification system. The case study method was used to analyze the data collected from six participants from the staff of the records center. The obtained result is the access classification policy using the socialization, externalization, combination, and internalization (SECI) model as a strategy to construct implicit and explicit knowledge. The guidelines for records security and access classification aim to guarantee the physical preservation of the records while ensuring the security of the information contained in the records. Knowledge management in the development of the guidelines for record classification and access is a reflection of the dialectical opposition that is taking place between the workspaces of a number of streams and the space of a number of places. Knowledge management of a record manager individual is a manifestation of power and function that are dominant by nature.
\end{abstract}

\section{Keywords—knowledge management, access, records}

\section{INTRODUCTION}

The records center at the Directorate General of Elementary and Secondary Education in the Ministry of Education and Culture Republic of Indonesia (Ditjen Dikdasmen Kemendikbud R.I.) stores records from all work units - both the substantive and facilitative. Substantive records are records from the organization's main activities or real operational activities. Facilitative records are records from complementary activities that ease and facilitate the work implementation in the organization [1]. Thus far, there have been no guidelines or restrictions to access to all the records from those work units stored in the records center at Ditjen Dikdasmen Kemendikbud R.I.; currently, the referred guideline for records service and access is the Standard Operational Procedure(SOP) of record access in the records center of the Directorate General of Elementary and Secondary Education as well as the Regulation of the Minister of Education and Culture of the Republic of Indonesia No. 68 of 2016 [2] regarding the general organization of records. Archivists allow access to any visitors who make a request, and often the record creators or the staff believe that they are still the rightful owner of the record. To avoid the loss or damage of artifacts, there needs to be a legitimate system of records security and access classification.
According to Azmi [3] and Rahmawati [4], archive security and access guidelines should reflect the authority of the record creator, the legal power of the organization, and the impact that will be caused by either damage to the record of restriction of users' rights. The creation of guidelines for the system of records security and access classification is based on the understanding of the archivists and the record manager about record access control and restriction and is developed using the Building Blocks of Knowledge Management in the socialization, externalization, combination, and internalization (SECI) model. This represents the activities that are directly knowledge-related, and their arrangement in the model forms two cycles: an inner cycle consisting of the building blocks of identification, acquisition, development, distribution, preservation, and use of knowledge, and an outer cycle consisting of all these activities plus goal setting and measurement [5]. The SECI knowledge management proposed by Nonaka uses a concept of a knowledge creation spiral to show how knowledge is created and shared in the organization arrangement through social interactions and collaborative process [6]. Nonaka and Takeuchi's view on knowledge creation using the SECI model involves knowledge transformation between tacit and explicit knowledge. This model describes four types of knowledge transformation: socialization, externalization, combination, and internalization [6].

The knowledge management of the record officer/manager in the records center is also obtained through a community of practice. Community of practice is a group of people sharing observations on a range of topics, or passions for a topic, and anyone can improve his or her knowledge and skill in those topics through sustainable interactions [7]. Access is the availability of records as a result of both a searching process of information that is in accordance with legal authorization and the existence of finding aids (ICA) [8]. The records center functions as a place where important but rarely used records are stored. Currently there are only record officers in the records center at Ditjen Dikdasmen Kemendikbud R.I. The position for archivist in the records center of Ditjen Dikdasmen Kemendikbud R.I is currently vacant because the previous acting archivist retired as of December 2018 (Decision Letter on January 2019).

Previous research [9] argues that, when granting record access, one must consider losses, damages, inaccurate filings, or undocumented changes. Additional research carried out by Azmi [3] discusses the four primary instruments of records management: office documentation, records classification, 
records retention schedule, and records security and access classification system.

Another study from Rahmawati [4] argues that a systematic record processing of government regulations must be balanced with the implementation of records security and access classification so as to protect the physical form of and the information contained in the records from damage and loss so that they will still be available, easy to read, intact, authentic, reliable, and safe. This paper does not focus on the content of the records security and access classification system; rather, it focuses on the knowledge management occurring in the development of the records security and access classification system in Ditjen Dikdasmen Kemendikbud R.I. The creation of dynamic knowledge in implementing records management guidelines is an update from this research. The update is done by linking the concept of knowledge management, records management, and the archivist's understanding about record access.

\section{RESEARCH PROBLEM}

The problem of this research is the dynamics between the knowledge management with the Building Blocks of Knowledge Management scheme and the knowledge management from the SECI model in the creation of record access in the records center at Ditjen Dikdasmen Kemendikbud R.I.

\section{RESEARCH PURPOSE}

The purpose of this research is to analyze the process of creating a record access policy and reconcile the record officers' Building Blocks of Knowledge Management model with the SECI model.

\section{RESEARCH METHODS}

This research uses a qualitative research approach, in which the researcher is highly dependent on the information provided by the study participants. Qualitative research is a means to explore and understand the meaning of individuals or groups related to the social or human problem [10]. It is a process of enquiry that draws data from the context in which events occur, in an attempt to describe these occurrences, as a means of determining the process in which events are embedded and the perspectives of those participating in the events, using induction to derive possible explanations based on observed phenomena. With that understanding, the researcher plays a significant role in observing the occurring phenomena [11].

The research took place over 10 months, from August 2018 to June 2019, in the records center at the Directorate General of Elementary and Secondary Education in the Ministry of Education and Culture, Republic of Indonesia. Data were drawn from six participants from the records management department at the records center at Ditjen Dikdasmen Kemendikbud R.I; each participant was given a pseudonym. The number of participants in a case study research can be lower without negatively impacting the research [12]. The participants were Ms. Titi (Head of Subdivision of Administration at Ditjen Dikdasmen); Mr. Eri (Information System Manager of the Administration at Ditjen Dikdasmen); Mr. Abi (Record Manager in the records center at Ditjen Dikdasmen); Mr. Uza (Record Manager in the records center at Ditjen Dikdasmen); Mr. Feri (Record
Manager in the records center at Ditjen Dikdasmen); and Mr. Mamad (Record Manager in the records center at DitjenDikdasmen).

The data collection techniques implemented were field observations and interviews with the Record Manager at the records center at Ditjen Dikdasmen Kemendikbud R.I. Direct observation is a way to find out how people behave and interact in certain situations [13]. An interview is a meeting of people to exchange information and ideas through questions and answers, so that meaning can be constructed in a particular topic [14]. Data were also collected through analysis of documents that support the research data; these include records from the Regulation of the Minister of Education and Culture of the Republic of Indonesia, SOP, records classification; PERKA ANRI; and other supporting documents related to the process of record access creation in the records center at Ditjen Dikdasmen Kemendikbud R.I. Data analysis was conducted based on the concept of knowledge management and record access.

\section{RESUlts AND DisCUSSION}

The records center at Ditjen Dikdasmen Kemendikbud R.I has actually existed for decades but has not performed its duties and functions effectively. There is still a low level of awareness importance of records stored in the records center.

The classification is made with an emphasis on the functions and activities of an organizational structure because the functions and activities are more stable than the administrative structure, which is often decentralized or restructured. When creating the classification, the data categorization is inseparable to the working units within the organization [1]. Classification is a process of categorizing or grouping records of specific issues in a logical, chronological, and systematical way based on the functions and activities of the creator's organization; it is a guideline for managing, organizing, and retrieving records [15].

Records security and the access classification system include regulations that restrict access rights to the records physically as well as to the information contained in them as a basis for determining which records are open to the public and which are confidential to protect the rights and responsibilities of the records creator and the users of records service [3].

Creating records security and an access classification system is an effort to limit both physical access to records and access to the information contained in the records. This is also related to the legal authority, and there is an intersection between the records security and access right classification system with the Law on Public Information Transparency that determined which information is excluded [16]. The system created for the records center at Ditjen Dikdasmen Kemendikbud R.I. through the Building Blocks of Knowledge Management model created by Probst (Harorimana) [5] represents the activities that are directly knowledge-related, and their arrangement in the model forms two cycles.

The archivists and record officers become the center of these cycles because they carry out all the phases in the cycles. The cycle is divided into two: an inner cycle consisting of the inner building blocks, starting from the knowledge identification which is identifying what 
knowledge is necessary in the creation process of the records security and access classification system, followed by knowledge acquisition, which is the process of acquiring the knowledge needed in the creation of record access in the records center at Ditjen Dikdasmen known from the previous phase of knowledge identification, and after acquiring the knowledge comes the knowledge development, which is the core process of the record access creation, which is the guideline of the records security and access classification system; after the creation process there is knowledge distribution to all parties from record officers to records users, and knowledge preservation is also carried out so that the created knowledge can continue to be utilized, and the knowledge is then used and applied in the organizational activities.

The outer cycle consists of knowledge goals and knowledge measurement, which are the phases where an evaluation is conducted on whether the goals of the performed knowledge management have been achieved or not, if they have then a measurement is conducted to see how far the knowledge has affected the organization's performance and interest.

The following figure demonstrates the creation process of records security and access classification system based on Building Blocks of Knowledge Management scheme.

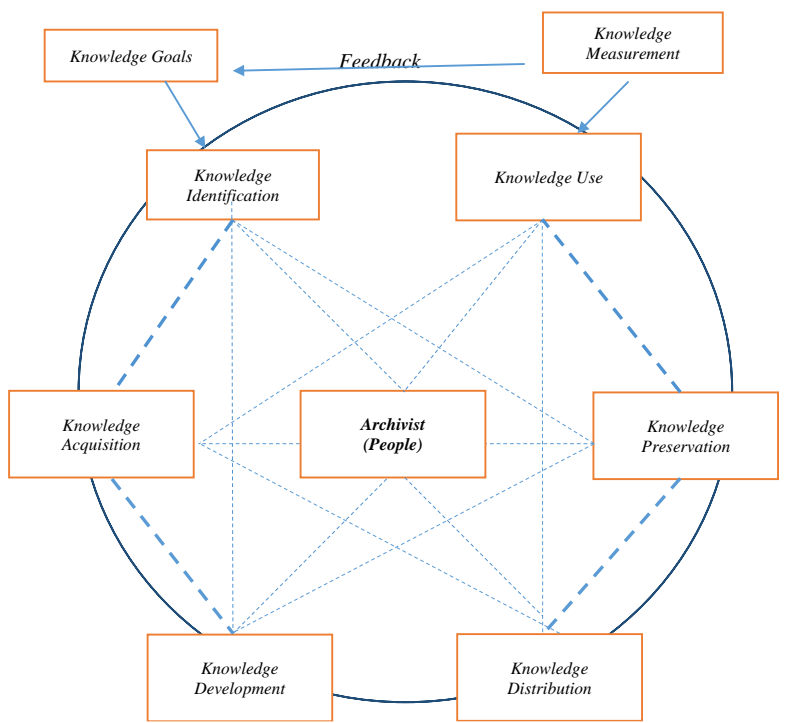

Fig. 1. The Building Blocks of Knowledge Management in the records center at Ditjen Dikdasmen Kemendikbud R.I. "Rendered"

The spiral concept of knowledge creation implemented in the records center at Ditjen Dikdasmen Kemendikbud R.I shows how knowledge is created and shared within an organizational arrangement through social interactions and collaborative processes. In this model, knowledge moves upward in an organization, starting at the individual level, moving to the group level, and then up to the firm level, involving a continual interplay between the tacit and explicit dimensions of knowledge [6].

\section{A. Socialization}

Socialization is the process of converting a tacit knowledge to a new tacit knowledge through shared experience and social interaction. This process can occur when people spend time together or live in the same environment.

At the records center at Ditjen Dikdasmen, the socialization phase occurs in the daily routine of carrying out everyone's own duties. Record officers share their tacit knowledge through interactions during discussions or casual chats in between carrying out their work routines or engaging in other activities in the workplace. Even when there was the late archivist, record creator who wanted to borrow the record, the archivist will let other record officers as his peer to know whether the required record was accessible or not, then the record officers got the required record.

\section{B. Externalization}

Externalization is the conversion of tacit knowledge to explicit knowledge, so that the knowledge can be shared to others and become new knowledge. The externalization process also happen in the records center at Ditjen Dikdasmen; the knowledge about records management and mainly about the record lending service has been converted from the tacit knowledge of the archivist to the form of a SOP for the record service, record classification, and retention schedule, which have been in place, albeit ineffectively, as many staff members are not familiar with the procedures.

\section{Combination}

Combination is creating new explicit knowledge by combining, categorizing, re-classifying, and synthesizing the existing explicit knowledge. The knowledge of each individual who interacts in encounters such as meetings, formal encounters such as internal meetings, when attending trainings or workshops, coordination meetings in the process of developing the records classification and access system, and many others as well as informal meetings during casual discussions is carried out in work spaces to exchange knowledge and information to reach an agreement upon the contents and forms of the records security and access classification system that is being developed. When an agreement is reached, the knowledge about the form and content of the records security and access classification system is stated in a printed form and referred to as a guideline.

\section{Internalization}

Internalization is when explicit knowledge is created and shared as new tacit knowledge, implemented in practical situation, and established as new routines. The absorption process of explicit knowledge to new tacit knowledge can also be supported by training progress or through reading documents or manuals. Internalization converts or integrates shared and/or individual experiences and knowledge into individual mental models. Once new knowledge is internalized, it is then used by employees who broaden it, extend it, and reframe it within their own existing tacit knowledge bases [18].

The creation process of records security and an access classification system in the records center at DitjenDikdasmen has not fully reached the phase of internalization yet; the internalization has only involved Ms. Titi, Mr. Abi, and Mr. Eri who are in leadership positions because they possess a background in archives. Similarly, 
many record officers are not involved in the development of the guideline of records security and access classification because they have no formal educational background in archives. This may include those like Mr. Uza, who have already obtained the status of civil servant and acquired the understanding of what records are by joining the trainings that ANRI organizes. Our research suggests that the internalization in the records security and access classification system should not be limited to those with formal education. Internalization may occur even though the knowledge constructed by these people's knowledge has not yet manifested in a written form.

\section{CONCLUSIONS}

Knowledge management in the development of the guidelines for record classification and access is a reflection of the dialectical opposition that is taking place between the workspaces of a number of streams and the space of a number of places. Space, in the knowledge management of a record manager individual, is a manifestation of power and function, which are dominant by nature. Creating guidelines for records security and an access classification system in the records center at Ditjen Dikdasmen Kemendikbud R.I. shows an interaction between the Building Blocks of Knowledge Management concept, a model in which knowledge moves from top to bottom incorporation, and the SECI model, which is constructive by nature. Knowledge management in the SECI model is not identified merely as discourse concerning archive and record management perspectives. Discourses manifest in the guidelines of record classification and access, which represent the knowledge management of the people involved in the process.

\section{REFERENCES}

[1] Lawanda, I. I. (2006). Manajemen data dan informasiperkantoran. Bogor: Akademia.

[2] Republik Indonesia. Peraturan Menteri Pendidikan dan Kebudayaan Republik Indonesia Nomor 68 Tahun 2016 Tentang Tata Kearsipan di Lingkungan Kementerian Pendidikan dan Kebudayaan
[3] Azmi. (2016). Signifikansi Empat Instrumen Pokok Pengelolaan Arsip Dinamis, Jurnal KearsipanANRI, Vol. 11: 15-38.

[4] Rahmawati, D. (2018). Penerapan Layanan Arsip Peraturan Pemerintah Sebagai Arsip Dinamis Inaktif Berdasarkan Klasifikasi Keamanan dan AksesArsip di Kementerian Sekretariat Negara Republik Indonesia, Diplomatika, Vol.1: 108-120.

[5] Harorimana, D. (2010). Cultural Implications of Knowledge Sharing, Management and Transfer: Identifying Competitive Advantage. New York: Information Science Reference.

[6] Agrifoglio, R. (2015). Knowledge Preservation Through Community of Practice: Theoretical Issues and Empirical Evidence. Switzerland: Springer.

[7] Wenger, E., McDermott, R., \& Snyder, W. M. (2002). Cultivating communities of practice $\left(1^{\text {st }}\right.$ ed.). Watertown, MA: Harvard Business School Press.

[8] International Council on Archives. (2012). Principles of Access to Archives (Committee on Best Practices and Standards Working Group on Access).

[9] Sari, M. W. (2013). Kebijakan Akses dan LayananArsip di Kantor Perpustakaan, Arsip dan Dokumentasi (KPAD) Kota Bukittinggi, JurnalIlmuInformasiPerpustakaan dan Kearsipan, Vol. 2, No. 1: 237245 .

[10] Creswell, J. W. 2009. Research Design: Qualitative, Quantitative, and Mixed Methods Approaches. Newbury Park: Sage Publications.

[11] Gorman, G. E., \& Clayton, P. (2005). Qualitative Research for the Information Professional: A Practical Handbook. London: Facet Publishing.

[12] Farquhar, J. D. (2012). Case study research for business. Sage

[13] Pickard, A. J. (2013). Research Methods in Information. Chicago: Neal-Schuman.

[14] Esterberg, K. G. (2002). Qualitative Methods In Social Research. Mc Graw Hill, New York.

[15] Muhidin, S. A., \& Dan Winata, H. (2016). ManajemenKearsipan. Bandung: Pustaka Setia.

[16] Mirmani, A., RatihSurtihanti, Y. B. R. (2016). Akses dan LayananArsip. Tangerang Selatan: Universitas Terbuka.

[17] Dalkir, K. Knowledge Management in Theory and Practice. Cambridge: MIT Press. 